\title{
LUCERNE MANAGEMENT FOR -THE CRITICAL SPRING PERIOD UNDER LIGHT LAND GRAZING
}

\author{
C. G. JANSON
}

Winchmore Irrigation Research Station, Ministry of Agriculture and Fisheries, Ashburton

\section{Abstract}

Spring is a critical period for unirrigated, light land grazing systems based on lucerne. Three management principles are described, which, on the basis of experimental evidence, can improve lucerne produc, tion in spring. These three principles are (1) the transfer of cool season growth through to the early spring, (2) delaying the grazing commencement time on the lucerne in spring as long as possible, and (3) rotationally grazing ewes and lambs over the pre-weaning period. Practical management techniques to aid the implementation of these principles on a farm scale are discussed.

\section{INTRODUCTION}

SPRING is probably the most critical period in the year for the light land property being managed without the benefit of irrigation and with a large percentage of its grazing area in lucerne.

Most of the year's herbage production takes place in spring: Also, most of the year's stock feed demands, both direct (in situ grazing) and indirect (fodder conservation), occur at this time. Management during this short period is critical as the farmer is feeding directly the young lamb, frequently his major income contributor.

As a consequence of these factors, improvements in either the feed supply or the efficiency of feed conversion over this period will be reflected in significant improvement in the performance of the total system.

Recently, some work at Winchmore has been directed at improving both these factors: the early spring feed supply and the efficiency of spring feed utilization in lucerne grazing systems. The work can be divided into three sections.

\section{TRANSFER OF COOL SEASON GROWTH}

Several overseas workers (Jackobs and Oldenmeyer, 1955; Kust and Smith, 1961; Smith 1965) and Douglas (1971) at Tara 
Hills, have recorded an increased yield of lucerne present in early spring by simply forgoing harvesting lucerne during winter or even autumn as well. However, the significance of these findings to lucerne grazing systems has apparently been almost completely overlooked. To verify and quantify this technique under lowland conditions, several trials were conducted at Winchmore under different conditions over two seasons.

Table 1, depicting the results of one trial conducted during autumn, winter and spring of 1973, illustrates the principles. The trial commenced at the beginning of March when all four treatments were closely grazed.

The treatments were:

1. Grazed autumn (April 30) and winter (June 5)

2. Grazed autumn (April 30) only

3. Grazed winter (June 5) only

4. Ungrazed autumn and winter.

These autumn/winter grazings were quick and hard. Lucerne yield at April 30 was $400 \mathrm{~kg} / \mathrm{ha} \mathrm{DM}$ and if grazed then was 250 $\mathrm{kg} / \mathrm{ha}$ by June 5. If the autumn growth at April 30 was left ungrazed, Lucerne yield by June 5 was $790 \mathrm{~kg} / \mathrm{ha}$.

Treatment 1, grazed autumn and winter, represents the usual cool season lucerne management system, and Table 1 shows how the spring growth following this treatment differs from that following Treatments 2, 3 and 4 which illustrate different autumn/ winter management systems.

Where winter growth only was carried forward (from beginning of May onwards-Treattncnt 2) a boost of $540 \mathrm{~kg} / \mathrm{ha}$ was recorded at the first spring grazing. With the additional boost at the second spring grazing, an extra $1320 \mathrm{~kg} / \mathrm{ha}$ of lucerne was produced over the spring period. However, where both autumnand winter-grown lucerne was carried forward (Treatment 4), there was an additional $980 \mathrm{~kg} / \mathrm{ha}$ of lucerne present at the first

TABLE 1: INFLUENCE OF AUTUMN/WINTER MANAGEMENT ON SPRING GROWTH

(kg/ha DM)

\begin{tabular}{lll}
\hline Treatment & Sep. $\mathbf{1 7}$ & Nov. $\mathbf{2 3}$ \\
\hline 1. Grazed autumn and winter & $\mathbf{1 6 6 0 \mathrm { cB }}$ & $1850 \mathrm{bA}$ \\
2. Grazed autumn only $\quad$. & $2210 \mathrm{abAB}$ & $\mathbf{2 6 3 0} \mathrm{aA}$ \\
3. Grazed winter only & $1990 \mathrm{bcAB}$ & $2070 \mathrm{abA}$ \\
4. Ungrazed autumn and winter & $\mathbf{2 6 4 0} \mathrm{aA}$ & $\mathbf{2 5 6 0} \mathrm{aA}$ \\
$\mathrm{CV}$ & $\mathbf{1 2 . 6 \%}$ & $\mathbf{1 5 . 9} \%$ \\
\hline
\end{tabular}


spring grazing. The significance of this very sizeable increase in early spring lucerne yield to the animal performance likely to be achieved on the area in the spring is considerable. Once again, as for Treatment 2, the benefit continued into the second grazing to give a total increase in spring yield of $1690 \mathrm{~kg} / \mathrm{ha} \mathrm{DM}$. All treatment differences had disappeared at subsequent harvests. Clearly, these increases in spring yield are considerably greater than the quantities of lucerne left ungrazed the previous autumn and winter.

The lack of any harmful effect on spring growth from autumn rather than winter grazing, cf. Treatments 2 and 3 , is in contrast to the findings of Douglas (1971) at Tara Hills. Indeed, the differences in spring growth between Treatments 2 and 3, albeit non-significant ones, suggest that, if lucerne is needed for grazing some time over the autumn/early winter period, the sooner it can be grazed and closed up the better. Grazing in the winter rather than the autumn as recommended by Douglas for the colder climatic conditions of Tara Hills apparently has no merit in terms of spring growth under the relatively mild winters of the lowland areas.

To investigate the value of this technique of cool season feed transference when autumn conditions are moist, the same treatments were applied in the 1972 and 1973 seasons to lucerne which was irrigated in March. Irrigation dramatically increased autumn growth which resulted in much greater lucerne yields being carried forward into the winter than under the drier autumn conditions depicted in Table 1. However, the same effects on spring yield occurred. The longer the lucerne was protected from grazing over the autumn/winter period prior to the spring, the greater was the increase in spring yield.

There are two final points in relation to these trials. First, the increased early spring yield that followed the saving of early winter and autumn lucerne came entirely in the form of fresh, leafy herbage, not as stalks and semi-decayed frosted material of low digestibility. Secondly, even Treatment 1, which depicted conventionally managed lucerne, was not grazed after June 5. A big proportion of lucerne is grazed much later than this. Latcr winter grazing would of course simply accentuate the spring yield superiority of winter and autumn/winter ungrazed lucerne.

\section{SPRING GRAZING COMMENCEMENT TIME}

General observations on different farm properties indicate that the time at which spring grazing is commenced on lucerne is an 
important determinant of its performance over the spring. Accordingly a trial was conducted to explore the significance of this factor.

Two grazing commencement times were compared. These were August 23 and September 6. After the initial grazing, subsequent grazings occurred on each treatment at live-weekly intervals, four such being taken from both treatments before drought curtailed growth in late December. The philosophy behind this approach of a common regrowth period for the two grazing commencement times assumes that, under actual grazing systems, the number of stock starting on the first paddocks of an early grazed system and a late grazed system will not be the same; there must initially be fewer on the early grazed system. If this is not so, obviously a common regrowth period will not result. Provided this qualification is recognized, the comparison is valid. Table 2 summarizes the outcome.

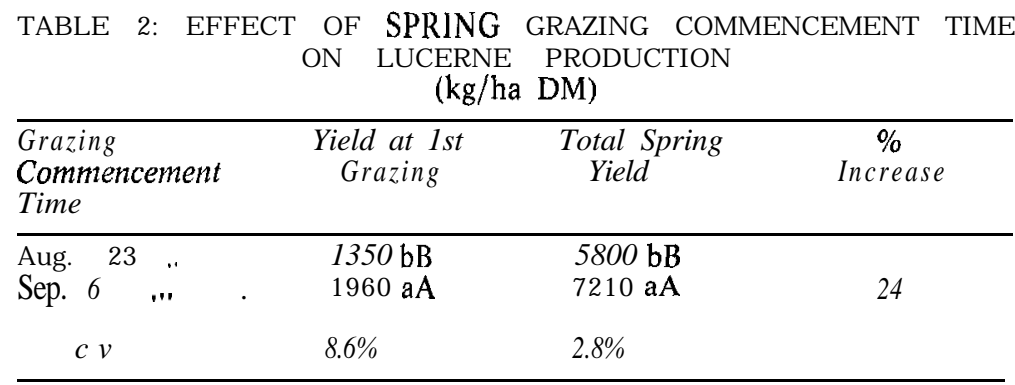

In this trial, delaying grazing commencement time by two weeks increased lucerne yield over the spring period by more than 1400 $\mathrm{kg} / \mathrm{ha}$, or $24 \%$. This is a very valuable yield improvement during the critical spring period.

However, in considering this result it is important to keep clearly in mind the basis on which the comparison was madei.e., a common regrowth period because, in practice, early grazing is frequently not associated with a lower stocking rate on the first paddocks of the rotation.

In these circumstances early grazing becomes almost inevitably associated with quick grazing and brief spells, or shorter regrowth periods between grazings, and a type of "whirlpool" effect can quickly develop.

Consequently, because in practice an early grazing commencement date is frequently associated with a quick rotation and brief spelling periods, the $24 \%$ difference in Table 2 under- 
estimates the importance of the grazing commencement time in spring.

There are several ways in which the spring grazing commencement time on the lucerne can be delayed. First, lambing date can be' adjusted. Generally, a property heavily reliant on lucerne for spring grazing should have a mean lambing date about three weeks later than a property in the same district reliant on grass/ clover pastures. This suggestion is not unreasonable in view of the ability of lucerne to continue growing into a summer drought longer than pasture.

Secondly, all the non-lucerne areas should be heavily stocked in spring before grazing is commenced on the lucerne.

Thirdly, the ability of the ewe to buffer sizeable restrictions to its intake over the first 2 to 3 weeks of lactation (Coop et al., 1972), can obviously be very usefully employed in this situation.

Finally, once grazing commences on the lucerne, the stock should begin with the most mature lucerne--i.e., the autumn/winter saved areas-and move progressively to the least mature, which will be those blocks grazed last in the winter.

\section{THE PRE-WEANING GRAZING SYSTEM}

On pasture systems the lambing to weaning period is a time when set-stocking is adopted to eliminate the problems associated with rotationally grazing mobs of ewes and lambs.

However, set-stocking of lucerne for prolonged periods during active growth has repeatedly been shown to be inimical to lucerne production and persistence (Peart, 1968; Smith, 1970; Brownlee, 1973). Therefore it seemed the set-stocking of lucerne even over this relatively short pre-weaning period should be examined.

Two grazing systems were compared: rotational grazing based on a four-paddock system and set-stocking. Border/Romney ewes (57 kg liveweight) with $130 \%$ of 1- to 2-day-old lambs were stocked at 30/ha in September when the lucerne was about 15 $\mathrm{cm}$ high.

The rotationally grazed ewes and lambs were moved on to their next paddock when the lucerne had been grazed to 1 to 2 $\mathrm{cm}$ from ground level. This was easily achieved with the periodic stocking rate of 120 ewes/ha on each paddock under grazing.

i'he set-stocked sheep slowly grazed down the lucerne relatively evenly over the whole area, consuming first the apices and uppermost leaves and then chewing steadily down the stem until they started to reject that in preference to the increasingly accessible 
new growth developing from the base of the plant. However, about four weeks after the trial started, it was clear that the lambs on the set-stocked unit would have to be weaned in 10 to 12 days, so a quarter of the unit was closed to grazing. Ten days later this quarter had an excellent cover of short, leafy lucerne, while the remaining three-quarters was by now closely grazed.

At this point, six weeks after the trial commenced, the setstocked lambs were weaned and the comparison of the two grazing systems was terminated. Ewes and lambs under both grazing systems were weighed and herbage cuts taken from all paddocks . to compare feed availability (Table 3 ).

TABLE 3: EWE AND LAMB LIVEWEIGHT (LW) CHANGE AND HEKBAGE AVAILABILITY

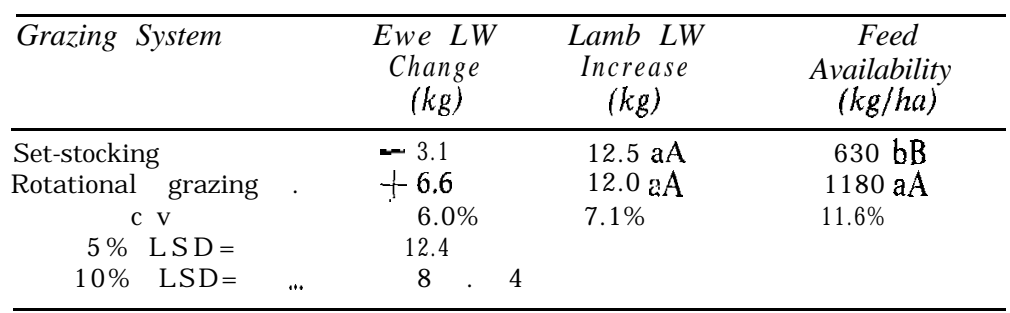

Feed availability under the rotationally grazed system after only six weeks was almost double that of the set-stocked system. The lambs grew equally well under both systems but the difference in ewe liveweight change (significant at the $10 \%$ level) expressed the difference in feed supply during the last part of the six-week period.

The reason for these differences in lucerne production is that set-stocking does not, and rotational grazing does, fit the growth pattern of lucerne. Under the reasonably high stocking rate imposed in this trial, the set-stocked sheep quickly removed the lucerne apices. This. interrupted growth of the immature lucerne until new buds were initiated. During this period there was little net increase in available herbage. Accordingly, the gap between available feed and animal requirement widened. Therefore, as the new shoots elongated from the base of - the plant they quickly became vulnerable to decapitation by the grazing stock, which, once again, interrupted growth.

Under rotational grazing, a greater proportion of the lucerne was allowed uninterrupted growth for a longer period. This system more closely fitted the growth pattern of lucerne and permitted 
greater herbage production than set-stocking, even when the comparison was operative for only a short time.

A cut, taken four weeks after the comparison terminated, recorded 30\% (430 kg/ha DM, significant at the 5\% level) more lucerne regrowth on the rotationally grazed than the set-stocked treatment. This difference had completely disappeared by later cuts.

Finally, three techniques are listed which are useful to the implementation of rotationally grazing unweaned ewes and lambs on a farm scale.

(1) Lambing should be concentrated into as brief a period as possible by synchronization. This reduces the range of lamb age and enables mobs to be assembled for rotational grazing sooner than normal.

(2) The position of the lucerne paddocks should be planned so that stock disturbance while rotationally grazing over this pre-weaning period is minimized.

(z) When shifting to a new paddock, if the gate is simply opened in the morning and the mob left undisturbed until evening, when the gate can be closed, few problems arise.

Over the last three to four seasons, several farmers in MidCanterbury have been successfully rotationally grazing mobs of round 500 ewes and young lambs on lucerne, using these techniques .

\section{ACKNOWLEDGEMENTS}

T. L. Knight for valuable technical assistance in all this work and P. D. Fitzgerald for statistical analyses of data.

\section{REFERENCES}

Brownlee, H., 1973. Aust. J. exp. Agric. Anim. Husb. 13: 259-62.

Coop, I. E.; Clark, V. R.; Claro, D., 1972. N.Z. Il agric. Res., 75: $203-8$. Douglas, J. A., 1971. N.Z. agric. Sci., 6 (2): 13-5.

Jackobs, J. A.; Oldenmeyer, D. L., 1955. Agron. J., 47: 169-70.

Kust, C. A.; Ṡmith, D., 1961. Crop Sci., 1: 267-9.

Peart, G. R., 1968. Proc. Aust Soc anim Prod., 7: 110-3.

Smith, D., 1965. Agron. J., 57: 463-6.

Smith, M. V.. 1970. Proc. 11th int. Grassld Congr.: 624-8. 